\title{
Etik Tüketici Davranışı: Marka Odaklı Karar Verme Tarzı ve Demografik Değişkenlere Göre İncelenmesi Üzerine Bir Araştırma
}

\section{Ethical Consumer Behavior: A Research Based on Brand-Oriented Consumer Decision- Making Style and Demographic Characteristics}

Başvuru Tarihi: 10.05.2019

Aybike Tuba Özden ${ }^{1}$

Kabul Tarihi: 13.09.2019

Öz

Tüketici karar verme tarzının faktörlerinden biri olan marka odaklılığı ve etik tüketici davranışı arasındaki ilişki, markaların hedef kitlelerini tanımaları açısından önem taşımaktadır. Nitekim markalar, sadece ürün etiketi olma durumundan uzaklaşarak tüketicilerle ilişki kuran bir kavrama dönüşmektedirler. Etik dışı tüketici davranışı, işletmelerin kârlılığını olumsuz etkilemektedir. Fakat tüketicilerin etik dışı davranmaları, sadece işletmeler için önemli değildir. Tüketicilerin etik davranmaları, toplumsal ahlak açısından da çok mühimdir. Bu nedenle tüketicilerin etik davranışlarının analiz edilmesi ve bu davranışlarına etki eden faktörlerin tespit edilmesi gerekmektedir. Dolayısıyla bu çalışmada, etik tüketici davranışı ve marka odaklı tüketici karar verme tarzı arasındaki ilişkinin araştırılması, işletmelere ve uygulayıcılara öneriler sunarak ilgili literatüre katkı sağlanması amaçlanmaktadır. Bu amaçla, 18 yaş üstü olan toplam 402 tüketiciye anket uygulanmıştır. Elde edilen bulgulara göre, etik tüketici davranışı ile marka odaklı tüketici karar verme tarzı arasında anlamlı ve negatif yönde ilişki olduğu tespit edilmiştir. Araştırmada ayrıca, tüketicilerin etik davranışlarının ve marka odaklı karar verme tarzlarının demografik özelliklerine göre farklılaştı̆̆ı görülmüştür.

Anahtar Kelimeler: Tüketici Karar Verme Tarzlarl, Marka Odaklılık, Etik Tüketici, Etik Tüketici Ölçeği, Demografik Özellikler

\begin{abstract}
The relationship between brand orientation and ethical consumer behavior, which is one of the factors of consumer decision making style, is important in terms of recognizing the target groups of brands. As a matter of fact, brands are becoming a concept that connects with consumers by moving away from only being a product label. Unethical consumer behavior affects adversely the profitability of businesses. However, unethical behaviors of consumers are not only important for businesses. The ethical behavior of consumers is also very important in terms of social morality. Therefore, it is necessary to analyze the ethical behaviors of consumers and to determine the
\end{abstract}

${ }^{1}$ Ondokuz Mayıs Üniversitesi Samsun MYO, aybike.ozden@omu.edu.tr, ORCID: 0000-0002-3133-3620 
factors affecting these behaviors. In this sense, in this study, it is aimed to investigate the relationship between ethical consumer behavior and brand-oriented consumer decision-making style and to contribute to the related literature by presenting suggestions to businesses and practitioners. For this purpose, a total of 402 consumers over 18 years of age were surveyed. According to the findings, it was found that there was a significant and negative relationship between ethical consumer behavior and brand-oriented consumer decision making style. In the study, it was seen that the ethical behaviors of the consumers and the brand-oriented decision making styles differ according to the demographic characteristics.

Keywords: Consumer Decision Making Styles, Brand Orientation, Consumer Ethics, Ethical Consumer Scale, Demographic Characteristics

\section{Giriş}

Günümüzde tüketim, tüm toplumu etkisi altına alan, toplumsal yapıyı hem ekonomik, hem psikolojik hem de sosyo-kültürel anlamda değiştiren ve dönüştüren, çok yönlü bir kavram olarak karşımıza çımaktadır. Tüketim toplumu olarak adlandırılan günümüz toplumlarında tüketiciler, tüketimi araç olmaktan çıkartarak amaç haline getirmektedirler. Bu durum, tüketicilerin birbirleriyle ve işletmelerle olan ilişkilerine hatta benlik algılarına yön verebilmekte, sadece tüketerek haz alan bireylerin oluşmasina neden olabilmektedir. Yaşanan bu süreç, yaşamın her alanında geçerli olan etik ilkelerin tüketim alanında da dikkate alınmasını zorunlu kılmaktadır. Etik; bireylerin, grupların, kurum ve işletmelerin veya toplumun iyi/doğru/yerinde/ahlaki olanı bulması ve uygulaması olarak açıklanabilir. Nitekim sosyal adalet, çevreye saygı, toplumsal ve bireysel sağlığın korunması gibi amaçlar etik tüketim davranışını gerekli kılmaktadır (Buğday ve Babaoğul, 2016, s. 199).

İşletmelerin pazarlama karması unsurlarını çevreye zarar vermeyecek şekilde tasarlamaları, tüketicileri yanıltıcı, aldatıcı pazarlama faaliyetleri yapmamaları veya ürün kullanımında tüm riskleri müşterileriyle paylaşmaları gibi etik sorumlulukları bulunmaktadır. Aynı zamanda tüketiciler de toplumsal sorumlulukları açısından etik değerleri benimsemeli ve bu yönde davranmalıdırlar. Bu bağlamda etik önemini hiç kaybetmeyecek bir unsurdur. Fiyatını ödemeden ürün almak, yanlış beyanda bulunarak iade veya değişim yapmak, ürünün ederinden daha düşük fiyat ödemek, taklit/korsan ürün kullanmak gibi etik tüketici davranışına uygun olmayan birçok davranış günümüzde yaşanan sorunlar arasındadır. Tüketicilerin etik dışı olan bu tüketim davranışları, işletmelerin kâr oranlarını olumsuz etkilemektedir (Levin vd., 2004, s. 48). $\mathrm{Bu}$ nedenle işletmelerin etik anlayışlarının araştırılması dışında tüketicilerin etik davranışlarının düzeylerinin, nedenlerinin, sonuçlarının veya bu davranışları etkileyen faktörlerin araştırılması önem taşımaktadır. Nitekim tüketicilerin satın alma, ürün kullanımı ve elden çıkarma aşamalarında çevre ve topluma en az zarar verecek şekilde davranma sorumlulukları bulunmaktadır (Dursun vd., s. 28). Dolayısıyla bu çalışmada, etik tüketici davranışı ve demografik faktörlerle olan ilişkisi üzerinde durulacaktır. 
Tüketici karar verme tarzlarının belirlenmesi, gittikçe karmaşı hale dönen tüketici davranışının, satın alma karar sürecinin ve bu süreci etkileyen dinamiklerin anlaşılmasını kolaylaştırarak işletmeler için alternatif pazar bölümlendirme kriterlerinin oluşmasına yardımcı olmaktadır (Dursun vd., 2013, s. 295). Bir ürünün diğer ürünlerden ayırt edilmesini sağlamak ve işaretlemesini tanımlamak amacının ötesine geçen marka; günümüzde bir kimliği olan, bu kimlik ile tüketicilerle iletişime geçen ve tüketiciler üzerinde psikolojik bir gücü olan kavrama dönüşmüştür. Ürün seçeneğinin çok fazla olduğu rekabet ortamında, işletmelerin güçlü markalar oluşturmaları gerekmektedir. Dolayısıyla marka odaklı karar verme tarzı olan tüketiciler, işletmelerin sürdürülebilir rekabet avantajı yaratabilmeleri açısından pazarın önemli bir hedef kitlesini oluşturmaktadırlar. Nitekim yapılan bu çalışmada, etik tüketici davranışı ile marka odaklı tüketici karar verme tarzı arasındaki ilişki incelenerek marka odaklı tüketicilere yönelik pazar bölümlendirme yapan işletmelere çeşitli öneriler sunulması ve ilgili literatüre katkı sağlanması amaçlanmaktadır.

\section{Literatür Analizi}

\section{Etik Tüketici}

Etik, birey ya da grup davranışlarının iyi ya da kötü olduğuna karar verilmesini ve yapılması veya yapılmaması gerekenlerin ne olduğunun anlaşılmasını sağlayan ilkeler bütünü olarak tanımlanabilir. Etik; toplumsal kuralları, iyi veya kötü, doğru veya yanlış davranış standartlarını ahlaki açıdan araştıran bilim dalıdır (Ertuhan ve Filizöz, 2011, s. 140). Marrow ve Richards (1996, s. 90), ahlaki ilkeler ve bu ilkelerin gerektirdiği davranış kuralları grubunu etik olarak tanımlamaktadırlar ve yazarlara göre bu kurallar, uygun olmayan davranışları önlemeyi, iyi olanı desteklemeyi ve teşvik etmeyi sağlamaktadır. Dolayısıyla etik için insanoğlunun yaşamının her alanında yer alan ve doğru olanı gösteren ahlaki bir kılavuzdur denilebilir. $\mathrm{Bu}$ bağlamda, insanların varlığından beri söz konusu olan tüketimin ve tüketici davranışının etik standartlarının olmaması düşünülemez.

Ferrell ve Gresham (1985), pazarlama alanında etik standartların gerekliliğini ortaya koyarak tüketici davranışında teleolojik ve deontolojik olarak iki etik yaklaşım olduğunu belirtmişlerdir. Hunt ve Vitell (1986, s. 6), deontolojik yaklaşımı tüketicilerin belirli davranışları, doğru ve yanlış ahlaki değerleri temel alarak sorgulama süreci olarak; teleolojik yaklaşımı ise tüketicilerin, davranışlarının iyi ve kötü sonuç odaklı değerlendirmelerini içeren bir süreç olarak tanımlamaktadırlar. Deontolojik yaklaşımda doğuştan gelen özelliklerin tüketicilerin davranışlarına yön vereceği ve toplumsal normların tüketici davranışı üzerinde etkili olabileceği kabul edilmektedir (Torlak, 2009, s. 125). Teleolojik yaklaşımda, tüketicilerin yapmış oldukları davranışların ahlaki değeri bu davranışlarının sonuçlarına göre belirlenmektedir (Ferrell ve Gresham, 1985, s. 89). Özetle deontolojik yaklaşım, davranışa neden olan niyetin; teleolojik yaklaşım ise davranışın sonucunun değerlendirilmesidir.

Tüketici etiği alanında en çok kabul görmüş tanımlamayı Muncy ve Vitell (1992) yapmışlardır. Muncy ve Vitell (1992, s. 298) tüketici etiğini, bireylerin veya grupların ürün elde etme, kullanma ve tüketim davranışlarına yön gösteren ahlaki ilkeler ve standartlar olarak tanımlamaktadırlar. Etik tüketiciler ise tüketim sırasında etik yaklaşımları dikkate alarak satın 
alma süreçlerini şekillendiren ve etik tüketme eğilimi gösteren tüketiciler olarak tanımlanmaktadır (Erciş ve Türk, 2016, s. 3).

Muncy ve Vitell (1992, s. 298), tüketicilerin etik inançları ve etik davranışları ile sosyodemografik özellikleri arasında ilişki olup olmadığını araştırdıkları ve Etik Tüketici Ölçeği’ni oluşturdukları çalışmalarında, tüketici davranışlarının etik açıdan doğru veya yanlış olarak değerlendirilebileceği dört boyuttan oluştuğunu belirtmektedirler:

- Yasal Olmayan Faaliyetlerden Aktif Olarak Yararlanma: Yasal olmayan faaliyetlerden bilinçli fayda sağlayan tüketicileri temsil etmektedir. Ürün etiketini değiştirmek, markette ücretini ödemeden yemek-içmek, kendi hatasından dolayı zarar gören ürünü önceden hasarlı göstermek gibi davranışlar bu faktörü temsil etmektedir.

- Diğerleri Pahasına Bir Durumdan Pasif Şekilde Yararlanma: Genelde hatalı olan faaliyetlerden duruma karşı bilinçli sessiz kalan tüketicileri temsil etmektedir. Fazla para üstü alınmasına rağmen sessiz kalmak, indirim elde etmek için çocuk yaşı hakkında yanlış bilgi vermek gibi davranışlar bu faktörü temsil etmektedir.

- Kısmen Zararsız Olan Bir Eylemden Yararlanma: Yaptıkları hatalı davranışın anlaşılmayacağını uman tüketicileri temsil etmektedir. Tarihi geçen indirim kuponu kullanmak, gelirde yanlış beyanda bulunarak vergi ödemesinde çıkar sağlamak, satın alınan ürünü mağazaya geri getirirken hediye olduğunu söylemek gibi davranışlar bu faktörü temsil etmektedir.

- Zararsız Olarak Algılanan Eylemden Yararlanma: Davranışlarını zararlı olarak algılamayan tüketicileri temsil etmektedir. Kopya bilgisayar yazılımı kullanmak, televizyondan film kaydetmek, çok fazla ürün denendiği halde satın almamak, bir müzik albümünü satın almadan kopyasını kullanmak gibi davranışlar bu faktörü temsil etmektedir.

Bu çalışmada Muncy ve Vitell (1992) tarafından geliştirilen ve 2005 yllında tekrar düzenlenen, Saray ve Hazer (2017) tarafından Türkçe uyarlamasının yapıldı̆̆ı Etik Tüketici Ölçeği kullanılmıştır. Orijinal ölçek 4 alt boyuttan ve 18 ifadeden oluşmaktadır ancak ölçeğin Türkçe uyarlamasında 2 faktör ve 8 ifade bulunmaktadır ve günümüz gelişmeleri gereği ölçeğin iki boyutlu bir ölçek olarak kullanılabileceği sonucuna varılmıştır (Saray ve Hazer, 2017, s. 258). Söz konusu 2 faktör "yasal olmayan bir durumdan aktif bir şekilde yararlanma" ve "zararsız olarak algılanan eylemlerden yararlanma" şeklindedir.

Tüketici etiği literatüründe tüketicilerin bir davranışın kötü olduğunu kabul etmelerine rağmen bu davranışı yapmaya devam etmeleri boyutu, "aktif olarak yararlanma"; tüketicilerin başkalarının etik olmayan davranış sergilemediği halde o koşuldan çıkar sağlama boyutu, "pasif olarak yararlanma"; tüketicilerin yaptıkları davranışın etik olup olmadığının tartışmalı olduğu durumlardan yararlanma boyutu, "tartışmaya açık konulardan aktif şekilde yararlanma" ve tüketicilerin firsatlardan yararlanmak için yanlış beyanda bulunması boyutu, “zararın/hilekârlığın olmaması” olarak tanımlanmaktadır (Erciş vd., 2017, s. 232). 
Oyman (2004, s. 79-80), tüketici etiği ile ilgili çalışmaları; 4 grupta toplandığını belirtmektedir. Bunlar; tüketicilerin mağaza vb. ortamda çalma davranı̧̧ı göstermeleri üzerine yapılan çalışmalar, tüketicilerin karar alma süreci ve bu süreci etkileyen faktörler üzerine yapılan çalışmalar, tüketicilerin işletmelerin eylemleri karşısında etiksel açıdan algılamaları üzerine yapılan çalışmalar ve tüketici etiğinde kültürlerarası karşılaştırmalar üzerine yapılan çalışmalardır. Tüketicilerin etik satın alma davranışını değerler, tutumlar, kişilik özellikleri, özsaygı, Makyavelizm, ihtiyaçlar ve etik ideolojiler gibi faktörler etkilemektedir. Forsthy (1980), etik ideolojileri relativistler ve idealistler olarak ikiye ayırmaktadır. Relativistler, etik değerlendirme yaparken evrensel ahlak kurallarını reddederek koşulların önemine vurgu yapmaktadırlar. İdealistler ise mutlak ahlaki değerlere bağlıdırlar. Yapılan araştırmalarda, genellikle etik ideolojiler ile etik tüketici davranışı arasındaki ilişkinin incelendiği görülmektedir (Al-Khatib vd. 1995; Al-Khatib vd. 1997; Arli ve Leo, 2016; Erffmeyer vd. 1999; Lu ve Lu, 2010; Rawwas, 2001; Rawwas vd. 1995; Swaidan vd. 2003; Tian ve Zhao, 2007).

Wilkes (1978), etik tüketici ile ilgili yapmış olduğu araştırmasında, hileli tüketici davranışlarının katılımcılar tarafından yanlış olarak değerlendirildiğini tespit etmiştir. Vitell ve Muncy (1992), Etik Tüketici Ölçeği'ni geliştirdikleri araştırmalarında işletmelere karşı olumlu tutum sahibi olan tüketicilerin daha etik davranma eğilimi taşıdıklarını tespit etmişlerdir. Vitell ve Muncy (1992), yapmış oldukları bir başka araştırmada daha yaşlı, daha az eğitimli ve az gelirli tüketicilerin etik duyarllıklarının yüksek olduğunu tespit etmişlerdir. Al-Khatib vd. (1995), Etik Tüketici Ölçeği’nin 4 alt boyutu ile idealizm, relativizm ve Makyavelizm arasındaki ilişkiyi incelemişlerdir. Aynı ölçeği kullanan Chan vd. (1998), tüketicilerin kültürel farklılıklara rağmen belirli bir durumun etik değerlendirmesini benzer şekilde yaptıklarını tespit etmişlerdir. AlKhatib vd. (1997), eğitim düzeyi yüksek tüketicilerin ahlaki gelişimlerinin yüksek olması nedeniyle daha etik davranışlar gösterdiklerini belirtmektedirler. Erfmeyer vd. (1999), kadın tüketicilerin erkek tüketicilere göre yasa dışı olmayan faaliyetleri hoş görmeye daha az istekli olduklarını, öğrencilerin kendi amaçlarına ulaşmak adına başkalarını manipüle etme eğiliminde olduklarını ve eğitim düzeyi ile tüketici etiği arasında ilişki olmadığını tespit etmişlerdir. Rawwas (2001, s. 203), tüketicilerin etik inançları ve ideolojileri ile makyavelist eğilimleri arasındaki ilişkiyi incelediği çalışmasında, materyalist özellikler taşıyan İrlanda, ABD ve Avustralyalı tüketicilerin etik ilkeler açısından daha pragmatik olduklarını, Mısır ve Lübnanlı tüketicilerin ise kolektif inançlara sahip olduklarını belirtmektedir. Vitell vd. (2001), yapmış oldukları araştırmada yaş ve gelir gibi tüketicilerin demografik özelliklerinin tüketici etiği üzerinde etkisi olmadığını tespit etmişlerdir. Hu vd. (2013), tüketici kişilik özelliklerinin tüketici etik inançlarını önemli ölçüde etkilediğini bulmuşlardır. Vitell vd. (2016), yapmış oldukları araştırmada bireysel bir tüketicinin ruhsal değeri ne kadar fazlaysa, tüketicinin etik eğilim gösterme ihtimalinin o kadar yüksek olduğunu tespit etmişlerdir. Arli ve Pekerdi (2016), dindar tüketicilerin idealizme daha fazla eğilim gösterdiklerini ve bu tüketicilerin dindar olmayan tüketicilere kıyasla daha güçlü etik inançlara sahip olduklarını tespit etmişlerdir. Gummerus, Liljander ve Sihlman (2017), etik tüketime duyulan duygusal bağlllğın olumlu olduğunu tespit etmişlerdir. Masuda vd. (2019), hayırsever bağış yapma olasılığı daha yüksek olan tüketicilerin etik ürünlere karşı olumlu tutumları bulunduğunu belirtmektedirler. 
Yurtsever (1998), Türkiye'de yaptığ çalışmasında, etik tüketici davranışı ile cinsiyet arasında ilişki olmadığını tespit etmiştir. Kavak (2000), yapmış olduğu araştırma ile tüketicilerin Makyavelizm düzeyleri arttıkça etik algılarının düştüğünü ortaya koymuştur. Varinli (2000), üniversite öğrencileri ile yaptığı çalışmasında eğitim düzeyi, meslek, ailenin geliri gibi demografik faktörlerin etik dışı tüketici davranışı üzerinde etkisi olmadığını belirtmektedir. Oyman (2004), tüketicilerin yaş, cinsiyet ve medeni durumlarının etiksel algılama ile ilişkisi olmadığını ancak eğitim düzeyi ve mesleğin etiksel algılama ile ilişkili olduğunu tespit etmiştir. Ecer (2006), yaş ve eğitim düzeyinin tüketici etiği ile pozitif yönde ilişkili olduğunu; cinsiyet, gelir, meslek ve medeni durumun ise tüketici etiğinin oluşumunda etkisi olmadığını belirtmektedir. Kavak vd. (2009), yaşlı ve kadın tüketicilerin daha yüksek etiksel tutuma sahip olduğunu tespit etmişlerdir. Torlak ve Tiltay (2009), gelir düzeyi düşük tüketicilerin etik dış1 davranış eğilimlerinin daha yüksek olduğunu belirtmektedirler. Hazer (2012), bekâr tüketicilerin daha yüksek oranda etik dışı davranış gösterdikleri sonucunu elde etmiştir. Hazer ve Öztürk (2013) ise daha yüksek geliri olan yaşlı tüketicilerin tüketici etiği algılamalarının daha yüksek olduğu sonucuna ulaşmışlardır.

\section{Marka Odaklı Tüketici Karar Verme Tarzı}

Tüketicilerin satın alma karar süreçleri; demografik, psikolojik, sosyo-ekonomik veya kültür gibi çeşitli faktörlerden etkilenmektedir. Bu süreci etkileyen faktörlerden biri olan tüketici karar verme tarzı, tüketicilerin kişiliğinin bir parçasını oluşturan zihinsel bir yönelim şeklinde tanımlanabilir (Sproles ve Kendall, 1986, s. 268). Bu yönelimi etkileyen 8 faktör bulunmaktadır: mükemmeliyetçilik/yüksek kalite odaklılık, marka odaklılık, yenilik-moda odaklılık, eğlence/haz odaklılık, fiyat odaklılık, düşünmeden alışveriş etme/dikkatsizlik/plansız alışveriş, çeşit karmaşası yaşama, alışkanlık/marka bağlılığı odaklılık (Sproles ve Sproles, 1990, s. 138).

$\mathrm{Bu}$ çalışmada, tüketici karar verme tarzı faktörlerinden biri olan marka odaklı karar verme tarzı ile etik tüketici davranışı arasındaki ilişki incelenecektir. Sproles ve Kendall (1986) tarafından geliştirilmiş olan Tüketici Karar Verme Tarzları Ölçeği’nin Dursun vd. (2013) tarafından Türkçe uyarlaması yapılmıştır. Bu çalışmada, Türkçe uyarlaması yapılmış olan ölçeğin, marka odaklı karar verme tarzı faktörünü ölçen 4 ifade kullanılmıştır. Marka odaklı karar verme tarzı olan tüketiciler, daha pahalı ve daha iyi bilinen markaları satın alma eğilimi göstermektedirler (Dursun vd., 2013, s. 295). Bu tüketiciler, yüksek fiyatlı ürünlerin daha kaliteli olduğuna inanmaktadırlar ve genellikle en çok bilinen markaları satın almayı tercih etmektedirler.

Hafstorm vd. (1992) kültürlerarası karşılaştırma yaptıkları çalışmalarında Koreli tüketicilerin Amerikalı tüketicilere göre daha yüksek marka bilincine sahip tüketiciler olduğunu tespit etmişlerdir. Bakwell ve Mitchell (2006), erkek tüketicilerin kadın tüketiciler gibi marka odaklı olduklarını tespit etmişlerdir. Cowart ve Goldsmith (2007), online alışveriş ile tüketici karar verme tarzı arasındaki ilişkiyi inceledikleri çalışmalarında online satın alma ile marka odaklılık arasında pozitif yönlü ilişki olduğunu tespit etmişlerdir. Ünal ve Erciş (2007), genç kuşak tüketicilerin marka bilinci ve tercihleri olduğunu ancak marka sadakati geliştirmediklerini belirtmektedirler. Lysonski ve Durvasula (2013), yapmış oldukları araştırmada tüketicilerin karar verme tarzlarındaki değişimi gözlemlemişler ve marka odaklı karar verme tarzı eğiliminde 
artış olduğunu tespit etmişlerdir. Engizek ve Şekerkaya (2016), X ve Y kuşağına mensup tüketicilerin marka odaklı tüketim yapma eğiliminde olduğunu belirtmektedirler. Ergin vd. (2016), eğlence/haz odaklı tüketiciler olarak adlandırdıkları tüketici grubunun marka odaklı olduğunu ve bu tüketicilerin, alışveriş yaparlarken temel amaçlarının eğlenme olduğunu belirtmektedirler. Anić vd. (2016); Hırvatistan, Makedonya ve Bosna Hersek'te yürüttüğü araştırmalarında, Hırvat tüketicilerin en düşük, Makedon tüketicilerin ise en yüksek marka odaklı eğilim gösterdiklerini belirtmektedirler.

Günümüzde tüketiciler, ürünlerin kendilerine sunmuş olduğu fonksiyonel faydaların dişında markaların taşıdığı sembolik anlamlardan dolayı da tüketim yapmaktadırlar. Bu nedenle tüketicilerin tıpkı sosyal ilişkilerinde olduğu gibi markalarla ilişki kurdukları düşünülebilir. Tüketiciler, benliklerini anlama ve başkaları ile iletişim kurma arayışından dolayı markaları seçmektedirler (Chernatory, 2010, s. 57). Nitekim markaların da bir kimliği ve kişiliği bulunmaktadır. $\mathrm{Bu}$ kimlik ve kişilikle bağ kuran tüketiciler, tercih ettikleri markaların kendilerini yansıttıklarını düşünebilmektedirler. Aaker (1997, s. 347), işletmelerin marka kişiliği aracılığıyla markalarını diğer markalardan farklılaştırabildiklerini belirtmektedir. $\mathrm{Bu}$ farklılaştırma, tüketici zihninde markanın başarılı bir şekilde konumlandırılmasını kolaylaştırmaktadır. Markanın kendisini temsil ettiğini düşünen tüketiciler, bu sürecin sonucunda marka sadakati geliştirebilmektedirler. Knapp (1999, s. 1), markaya karşı olumlu duyguları olan tüketicilerin o markanın ürünlerini düzenli şekilde kullandıklarını belirtmektedir. Tüketicilerin marka ile olan ilişkileri ve etik davranışları arasındaki ilişkiye bakıldığında marka sadakati ile ilgili yapılan çalışmalar göze çarpmaktadır. Schröder ve McEahhern (2005), etik satın alma ve marka sadakati arasında ilişkinin negatif yönlü olduğunu tespit etmiş olmakla birlikte tüketicilerin şirketlerden sosyal sorumluluk beklentilerinin yüksek olduğunu belirtmektedirler. Jegethesan vd. (2012) yapmış oldukları araştırmalarında, tüketicilerin ürünün etik özelliklerine önem verdiklerini ancak marka sadakati arttıkça etik satın alma davranışının azaldığını tespit etmişlerdir.

Meydan (2017), etik tüketim ile ilgili uluslararası çalışmaları incelediği araştırmasında, etik olmayan davranışların bilinmesine rağmen genç tüketicilerde; marka sadakati, sosyal çevreye uyum veya ürünün özelliğini sevme gibi unsurların etik tüketimin önüne geçtiğinin tespit edildiğini belirtmektedir. Tüketicilerin etik bilgiye ve etik ürünlere ulaşımlarının zor olduğu durumlarda, etik tüketimi tercih etmedikleri ancak eğitim seviyesi yüksek tüketicilerin kullandıkları marka yerine etik tüketimi seçme eğilimi gösterdikleri görülmektedir (Meydan, 2017, s. 243).

\section{Yöntem ve Bulgular}

\section{Araştırmanın Amacı ve Önemi}

Bireylerin, toplum tarafından genel kabul gören normlara uygun davranışları etik davranış olarak tanımlanmaktadır (Owunwanne vd., 2010, s. 61). Bu bağlamda etik tüketici davranışı için tüketicilerin, tüketim sürecinde doğru/iyi olarak tanımlanacak şekilde davranmalarıdır denilebilir. İşletmelerin ve tüketicilerin etkileşim içinde olduğu pazarda çeşitli çıkar çatışmalarının yaşanılma ihtimali hem işletmeler hem de tüketiciler açısından etik bir anlayışla 
hareket edilmesini zorunlu kılmaktadır. İşletmelerden beklenen etik anlayışın tüketiciler tarafından benimsenmemesi, sağlıklı bir etkileşim kurulmasına engel oluşturacaktır. Dolayısıyla bu çalışmanın amacı, demografik faktörlerin etik tüketici davranışı üzerinde etkisinin olup olmadığının ve etik tüketici davranışı ile marka odaklı tüketici karar verme tarzı arasındaki ilişkinin tespit edilmesidir. Bu doğrultuda, elde edilen sonuçların, işletmelerin markaları ile ilgili isabetli stratejiler geliştirmelerine yardımcı olması hedeflenmektedir.

\section{Araştırmanın Hipotezleri}

Hazer (2012), yapmış olduğu çalışmada tüketici etiğinin oluşumunda tüketicilerin yaşının önemli rol oynadığını tespit etmiştir. Ecer (2006) ve Oyman (2004) ise etik tüketici davranışı ile yaş arasında anlamlı bir ilişki olmadığını belirtmektedirler. Muncy ve Vitell (1992, s. 306), eğitim ve gelir düzeyinin etiksel davranışları etkilediği sonucuna ulaşmışlardır. Etik tüketici davranışı ile ilgili yapılan çalışmalarda tüketicilerin cinsiyetleri ile etik tüketici davranışları arasındaki ilişki ile ilgili farklı sonuçlara ulaşılmıştır. Örneğin Swaidan vd., (2006, s. 13), etik tüketici davranışı ile cinsiyet arasında ilişki olmadığını belirtmektedirler. Bu doğrultuda;

H1. Tüketicilerin etik davranışları, cinsiyetlerine göre farklılık göstermektedir.

H1a. Tüketicilerin yasal olmayan bir durumdan aktif bir şekilde yararlanma faktörü, cinsiyetlerine göre farklıllk göstermektedir.

H1b. Tüketicilerin zararsız olarak algılanan eylemlerden yararlanma faktörü, cinsiyetlerine göre farkllık göstermektedir.

H2. Tüketicilerin etik davranışları, yaş gruplarına göre farklılık göstermektedir.

H2a. Tüketicilerin yasal olmayan bir durumdan aktif bir şekilde yararlanma faktörü, yaş gruplarına göre farklllık göstermektedir.

H2b. Tüketicilerin zararsız olarak algılanan eylemlerden yararlanma faktörü, yaş gruplarına göre farklılık göstermektedir.

H3. Tüketicilerin etik davranışları, eğitim düzeylerine göre farklılık göstermektedir.

H3a. Tüketicilerin yasal olmayan bir durumdan aktif bir şekilde yararlanma faktörü, eğitim düzeylerine göre farkllılk göstermektedir.

H3b. Tüketicilerin zararsız olarak algılanan eylemlerden yararlanma faktörü, eğitim düzeylerine göre farkllılk göstermektedir.

H4. Tüketicilerin etik davranışları, gelir düzeylerine göre farklılık göstermektedir.

H4a. Tüketicilerin yasal olmayan bir durumdan aktif bir şekilde yararlanma faktörü, gelir düzeylerine göre farkllılk göstermektedir.

H4b. Tüketicilerin zararsız olarak algilanan eylemlerden yararlanma faktörü, gelir düzeylerine göre farkllık göstermektedir.

Tüketiciler, lüks markaların taklit ürünlerinin satın alınmasını etik olmayan bir davranış olarak nitelendirmektedirler (Özkoç vd., 2018, s. 325). Bu doğrultuda;

H5. Tüketicilerin etik davranışları, marka odaklı karar verme tarzlarına göre farklılık göstermektedir.

H5a. Tüketicilerin yasal olmayan bir durumdan aktif bir şekilde yararlanma faktörü, marka odaklı karar verme tarzlarına göre farklılık göstermektedir. 
H5b. Tüketicilerin zararsız olarak algılanan eylemlerden yararlanma faktörü, marka odaklı karar verme tarzlarına göre farklılık göstermektedir.

Tüketicilerin karar verme tarzlarının demografik özelliklerine göre farklılık gösterdiğini tespit eden araştırmalar bulunmaktadır (Anić vd., 2006; Özden, 2019; Shim, 1996). Bu doğrultuda;

H6. Tüketicilerin marka odaklı tüketici karar verme tarzları, demografik özelliklere göre farklılik göstermektedir.

H6a. Tüketicilerin marka odaklı tüketici karar verme tarzları, cinsiyetlerine göre farklılık göstermektedir.

H6b. Tüketicilerin marka odaklı tüketici karar verme tarzları, yaş gruplarına göre farklılık göstermektedir.

H6c. Tüketicilerin marka odaklı tüketici karar verme tarzları, eğitim düzeylerine göre farklılık göstermektedir.

H6d. Tüketicilerin marka odaklı tüketici karar verme tarzları, gelir düzeylerine göre farklılık göstermektedir.

Belirtilen hipotezler doğrultusunda araştırmanın modeli Şekil 1'deki gibidir.

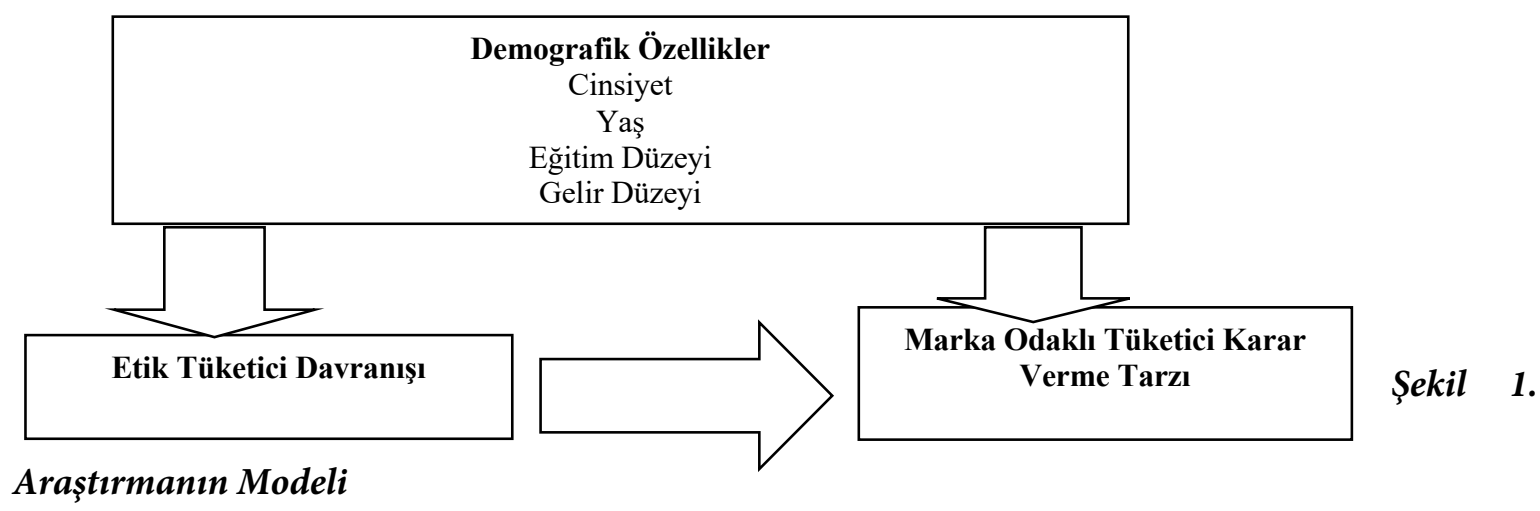

\section{Araştırmanın Örneklemi}

25 Mart- 10 Mayıs 2019 tarihleri arasında Ankara ve Samsun'da uygulanan anketler, 18 ve üzeri yaş aralığındaki tüketicilere uygulanmıştır. Katılımcılar öğrenciler, akademisyenler, AVM'lerde alışveriş yapanlar, liselerde çalışan öğretmen ve memurlardan oluşmaktadır. Ayrıca anket formu online olarak çeşitli sosyal medya platformlarında paylaşılarak kullanıcıların anket formunu online ortamda doldurmaları sağlanmıştır. Online olarak ve yüz yüze yapılan anketler ile toplamda 420 tüketiciye ulaşılmış, eksik ve hatalı doldurulan anketlerin elenmesi sonucu toplam 402 anket değerlendirmeye alınmıştır.

\section{Veri Toplama Yöntemi ve Araçları}

$\mathrm{Bu}$ çalışmada veri toplama aracı olarak anket kullanılmıştır. Anket formunun birinci bölümünde katılımcıların etik tüketici davranışlarını ölçmeye yönelik Muncy ve Vitell (1992) tarafından geliştirilen ve 2005 yılında tekrar düzenlenen, Saray ve Hazer (2017) tarafından 
Türkçe uyarlamasının yapıldığı Etik Tüketici Ölçeği kullanılmıştır. Ölçeğin Türkçe uyarlamasında 2 faktör ve 8 ifade bulunmaktadır. Etik Tüketici Ölçeği'nde yer alan ifadelere tüketiciler; Kesinlikle Yanlış Olduğunu Düşünüyorum (1 puan), Yanlış Olduğunu Düşünüyorum (2 puan), Ne Doğru ne Yanlış (3 puan), Doğru Olduğunu Düşünüyorum (4 puan), Kesinlikle Doğru Olduğunu Düşünüyorum (5 puan) şeklinde görüş belirtmişlerdir. Etik Tüketici Ölçeği'nde alınan yüksek puanlar tüketicilerin etik davranışta bulunmadıklarını, düşük puanlar ise etik tüketim davranışında bulunduklarını ifade etmektedir (Saray ve Hazer, 2017, s. 283). Anket formunun ikinci bölümü; Sproles ve Kendall (1986) tarafından geliştirilmiş olan Dursun vd. (2013) tarafından Türkçe uyarlamasının yapıldığı Tüketici Karar Verme Tarzları Ölçeği'nin, marka odaklı tüketici karar verme tarzı faktörüne yönelik 4 ifadesinden oluşmaktadır. Tüketici Karar Verme Tarzları Ölçeği'nde yer alan değişkenler 5'li Likert ölçeğinde sorulmuştur. Likert ölçeğinde değerlendirme (1) Kesinlikle Katılmıyorum, (2) Katılmiyorum, (3) Fikrim Yok, (4) Katılıyorum, (5) Kesinlikle Katılıyorum şeklindedir. Anket formunun son bölümü tüketicilerin cinsiyetleri, yaşları, eğitim durumları ve gelir düzeylerine ait bilgilerin olduğu kişisel bilgiler kısmından oluşmaktadır.

\section{Verilerin Analizi}

Analizler IBM SPSS Statistics 23 paket programı üzerinden yapılmıştır. Çalışma verileri değerlendirilirken kategorik değişkenler (örneğin cinsiyet) için sıklıklar (sayı, yüzde), sayısal değişkenler (örneğin marka odaklılık skorları) için ise tanımlayıcı istatistikler (ortalama, standart sapma, medyan, minimum, maksimum) verilmiştir.

Sayısal değişkenlerin normallik varsayımları Kolmogorov Smirnov normallik testi ile incelenmiş ve değişkenlerin normal dağılmadıkları görülmüştür. Bu nedenle çalışmada parametrik olmayan istatistiksel yöntemlerden yararlanılmıştır.

İki Bağımsız grup arasındaki farklılıklar Mann Whitney U testi ile incelenmiştir. İki bağımsız sayısal değişken arasındaki ilişki Spearman's Rho korelasyon katsayısı ile yorumlanmıştır. İkiden fazla bağımsız grup arasındaki farklılıklara ise Kruskall Wallis analizi ile bakılmıştır. Kruskal Wallis analizinde fark çıkması durumunda farklılığın hangi gruptan kaynaklandığını belirleyebilmek için ikili karşılaştırma yapılmışve Bonferroni düzeltmesi yapılmıştır. Çalışmada kullanılan ölçeklerin güvenirliği Cronbach Alfa iç tutarlılık katsayısı ile incelenmiştir. Analizlerde istatistiksel anlamlılık 0,05 düzeyinden yorumlanmıştır.

\section{Bulgular}

Araştırmada kullanılan ölçekler ve alt boyutlarının tanımlayıcı istatistikleri, güvenirlik ve normallik değerleri Tablo 1'de sunulmuştur. 
Tablo 1. Etik Tüketici Ölçeği ve Alt Boyutları ile Marka Odaklılık İçin Tanımlayıcı İstatistikler, Güvenirlikler, Normallikler

\begin{tabular}{|c|c|c|c|c|c|c|c|}
\hline & Ortalama & St. Sapma & Medyan & Min. & Mak & $\begin{array}{l}\text { Cronbach } \\
\text { Alfa }\end{array}$ & $\begin{array}{l}\text { Kolmogorov } \\
\text { Smirnov (p) }\end{array}$ \\
\hline Yasal Olmayan Bir & & & & & & & \\
\hline $\begin{array}{l}\text { Durumdan Aktif Bir } \\
\text { Şekilde Yararlanma }\end{array}$ & 2,10 & 1,337 & 1,50 & 1,00 & 5,00 & 0,922 & 0,000 \\
\hline $\begin{array}{l}\text { Zararsız Olarak Algılanan } \\
\text { Eylemlerden Yararlanma }\end{array}$ & 2,80 & 1,375 & 2,50 & 1,00 & 5,00 & 0,891 & 0,000 \\
\hline Etik Tüketici Ölçeği & 2,45 & 1,270 & 2,00 & 1,00 & 5,00 & 0,934 & 0,000 \\
\hline Marka Odaklılık & 3,18 & 1,455 & 3,63 & 1,00 & 5,00 & 0,928 & 0,000 \\
\hline
\end{tabular}

Çalışmaya katılan kişilerin "yasal olmayan bir durumdan aktif bir şekilde yararlanma” alt boyutu skorlarının ortalaması 2,10 $\pm 1,337$ iken "zararsız olarak algılanan eylemlerden

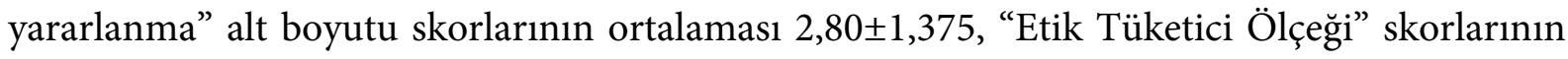
ortalaması 2,45 $\pm 1,270$ ve "marka odaklılı" alt boyutu skorlarının ortalaması ise $3,18 \pm 1,455$ olduğu görülmektedir.

Uygulanan Cronbach Alfa güvenirlik analizi sonucunda 4 maddeden oluşan "yasal olmayan bir durumdan aktif bir şekilde yararlanma" alt boyutunun, 4 maddeden oluşan "zararsız olarak algılanan eylemlerden yararlanma” alt boyutunun, 8 maddeden oluşan Etik Tüketici Ölçeği'nin ve 4 maddeden oluşan "marka odaklılık" alt boyutunun güvenirliklerinin yüksek seviyede oldukları görülmüştür $(\alpha>0,700)$.

Uygulanan Kolmogorov Smirnov analizi sonucunda "Etik Tüketici Ölçeği” ve alt boyutlarının ve marka odaklılık alt boyutunun dağılımlarının normal olmadıkları görülmüştür $(p<0,05)$. Bu nedenle çalışmada bu skorlarla ilgili yapılan analizlerde parametrik olmayan testlerden yararlanılmıştır.

Katılımcıların demografik özelliklerine ilişkin bulgular Tablo 2'deki gibidir. 
Tablo 2. Demografik Özelliklere İlişkin Dağılımlar

\begin{tabular}{lll}
\hline (n=402) & Sayı & Yüzde \\
\hline Cinsiyet & 204 & 50,7 \\
Kadın & 198 & 49,3 \\
Erkek & 100 & \\
Yaş & 101 & 24,9 \\
$18-25$ Yaş & 93 & 25,1 \\
26-35 Yaş & 71 & 23,1 \\
36-45 Yaş & 37 & 17,7 \\
46-55 Yaş & & 9,2 \\
56 Yaş ve Üzeri & 28 & \\
Eğitim Durumu & 72 & 7,0 \\
İlköğretim & 81 & 17,9 \\
Lise & 106 & 20,1 \\
Ön Lisans & 68 & 26,4 \\
Lisans & 47 & 16,9 \\
Yüksek Lisans & & 11,7 \\
Doktora & 102 & \\
Gelir Durumu & 143 & 25,4 \\
2021 TL'den Az & 83 & 35,6 \\
2021-5000 TL & 51 & 20,6 \\
5001-8000 TL & 23 & 12,7 \\
8001-11000 TL & & 5,7 \\
11000 TL Üzeri & &
\end{tabular}

Çalışmaya katılan kişilerin \%50,7'si kadın iken \%49,3'ü erkektir. \%24,9'u 18-25 yaş grubunda iken $\% 25,1$ 'i $26-35$, \%23,1'i $36-45$, \%17,7'si $46-55$ ve $\% 9,2$ 'si ise 56 ve üzeri yaş grubundadır. \%7'sinin eğitim durumu ilköğretim iken \%17,9'unun lise, \%20,1'inin ön lisans, \%26,4'ünün lisans, \%16,9'unun yüksek lisans ve \%11,7'sinin ise doktoradır. \%25,4'ünün gelir durumu 2021 TL'den az iken \%35,6'sının 2021-5000 TL aralı̆̆ında, \%20,6'sının 5001-8000 TL, \%12,7'sinin 8001-11000 TL ve \%5,7'sinin ise 11000 TL üzeridir.

Etik Tüketici Ölçeği ve alt boyutları ile marka odaklılık arasındaki ilişkilerin incelenmesine ilişkin sonuçlar Tablo 3'deki gibidir.

Tablo 3. Etik Tüketici Ölçeği ve Alt Boyutları ile Marka Odaklılık Arasındaki İlişkilerin İncelenmesi

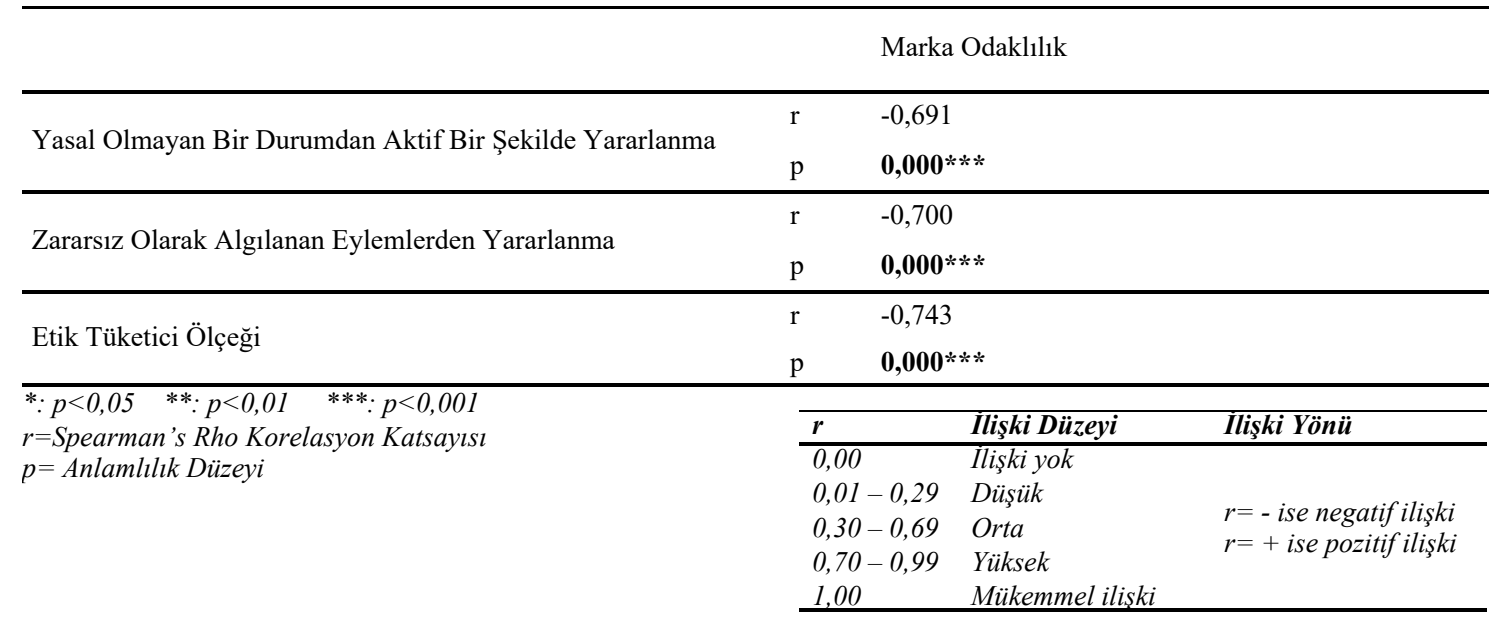


Uygulanan korelasyon analizi sonucunda "marka odaklılı" ile "yasal olmayan bir durumdan aktif bir şekilde yararlanma" arasında orta düzeyde negatif yönde ( $r=-0,691 ; p<0,001)$, "marka odaklılık" ile "zararsız olarak algılanan eylemlerden yararlanma” arasında yüksek düzeyde negatif yönde ( $r=-0,700 ; p<0,001)$, “marka odaklılık" ile "Etik Tüketici Ölçeği” arasında yüksek düzeyde negatif yönde $(r=-0,743 ; p<0,001)$ anlamlı doğrusal bir ilişki olduğu söylenilebilir. $\mathrm{Bu}$ doğrultuda; H5 (Tüketicilerin etik davranışları marka odaklı karar verme tarzlarına göre farklılık göstermektedir), H5a (Tüketicilerin yasal olmayan bir durumdan aktif bir şekilde yararlanma faktörü marka odaklı karar verme tarzlarına göre farklılık göstermektedir.) ve H5b (Tüketicilerin zararsız olarak algılanan eylemlerden yararlanma faktörü marka odaklı karar verme tarzlarına göre farklılık göstermektedir.) hipotezleri doğrulanmıştır.

Katılımcıların etik tüketici davranışları ve marka odaklı karar verme tarzlarının cinsiyetlerine göre gösterdikleri farklılıklar Tablo 4'deki gibidir.

Tablo 4. Cinsiyete Göre Etik Tüketici Ölçeği ve Alt Boyutları ile Marka Odaklılık Farklılıklarının Incelenmesi

\begin{tabular}{|c|c|c|c|c|c|c|c|}
\hline & & Sayı & Ortalama & St.Sapma & Medyan & $\mathbf{Z}$ & $\mathbf{p}$ \\
\hline Yasal Olmayan Bir Durumdan & Kadın & 204 & 2,25 & 1,395 & 1,75 & \multirow{2}{*}{$-1,738$} & \multirow{2}{*}{0,082} \\
\hline Aktif Bir Şekilde Yararlanma & Erkek & 198 & 1,95 & 1,259 & 1,25 & & \\
\hline $\begin{array}{lll}\text { Zararsiz } & \text { Olarak } & \text { Algilanan }\end{array}$ & Kadın & 204 & 2,95 & 1,438 & 3,00 & \multirow{2}{*}{$-1,937$} & \multirow{2}{*}{0,053} \\
\hline Eylemlerden Yararlanma & Erkek & 198 & 2,65 & 1,293 & 2,25 & & \\
\hline \multirow{2}{*}{ Etik Tüketici Ölçeği } & Kadın & 204 & 2,60 & 1,325 & 2,19 & \multirow{2}{*}{$-1,853$} & \multirow{2}{*}{0,064} \\
\hline & Erkek & 198 & 2,30 & 1,194 & 1,94 & & \\
\hline \multirow[b]{2}{*}{ Marka Odaklılık } & Kadın & 204 & 2,95 & 1,442 & 2,88 & \multirow[b]{2}{*}{$-3,043$} & \multirow[b]{2}{*}{$0,002 *$} \\
\hline & Erkek & 198 & 3,42 & 1,434 & 4,00 & & \\
\hline
\end{tabular}

*:p<0,05 (İstatistiksel olarak anlamli) Z: Mann Whitney $U$

Uygulanan Mann Whitney U analizi sonucunda kadın ve erkek katılımcılar arasında "yasal olmayan bir durumdan aktif bir şekilde yararlanma", "zararsız olarak algılanan eylemlerden yararlanma", "Etik Tüketici Ölçeği” skorları bakımından istatistiksel olarak anlamlı farklılık bulunmamaktadır ( $\mathrm{p}>0,05)$. Bu doğrultuda H1 (Tüketicilerin etik davranışları cinsiyetlerine göre farklılık göstermektedir.), H1a (Tüketicilerin yasal olmayan bir durumdan aktif bir şekilde yararlanma faktörü cinsiyetlerine göre farklılık göstermektedir.) ve H1b (Tüketicilerin zararsız olarak algılanan eylemlerden yararlanma faktörü cinsiyetlerine göre farklılık göstermektedir.) hipotezleri reddedilmiştir.

Kadın ve erkek katılımcılar arasında "marka odaklılık" skorları bakımından istatistiksel olarak anlamlı farklılık bulunmaktadır $(\mathrm{p}<0,05)$. Bu doğrultuda H6a (Tüketicilerin marka odaklı tüketici karar verme tarzı cinsiyetlerine göre farklılık göstermektedir.) hipotezi doğrulanmıştır. Buna göre erkeklerin "marka odaklılık” skorları kadınlardan anlamlı derecede daha fazladır. Katılımcıların etik tüketici davranışlarının ve marka odaklı karar verme tarzlarının yaş gruplarına göre gösterdikleri farklılıklar Tablo 5'deki gibidir. 
Tablo 5. Yaş Gruplarına Göre Etik Tüketici Ölçeği ve Alt Boyutları ile Marka Odaklılık Farklılıklarının İncelenmesi

\begin{tabular}{|c|c|c|c|c|c|c|c|}
\hline & & Sayı & Ortalama & St.Sapma & Medyan & K.W. & $\mathbf{p}$ \\
\hline & $1.18-25$ Yaş & 100 & 2,24 & 1,461 & 1,25 & & \\
\hline Yasal Olmayan Bir & 2.26-35 Yaş & 101 & 2,03 & 1,136 & 1,50 & & \\
\hline Durumdan Aktif Bir & 3.36-45 Yaş & 93 & 1,84 & 1,215 & 1,25 & 3,387 & 0,495 \\
\hline \multirow[t]{2}{*}{ Şekilde Yararlanma } & 4.46-55 Yaş & 71 & 2,15 & 1,299 & 1,75 & & \\
\hline & 5.56 Yaş ve Üzeri & 37 & 2,47 & 1,737 & 1,25 & & \\
\hline \multirow{2}{*}{$\begin{array}{l}\text { Zararsiz Olarak } \\
\text { Algılanan }\end{array}$} & $1.18-25$ Yaş & 100 & 3,22 & 1,411 & 3,88 & & \\
\hline & 2.26-35 Yaş & 101 & 2,97 & 1,378 & 3,00 & & \\
\hline \multirow{2}{*}{ Eylemlerden } & 3.36-45 Yaş & 93 & 2,37 & 1,290 & 2,00 & 20,428 & Fark \\
\hline & 4.46-55 Yaş & 71 & 2,63 & 1,212 & 2,25 & & $3-1,2$ \\
\hline \multirow{3}{*}{ Yararlanma } & 5.56 Yaş ve Üzeri & 37 & 2,64 & 1,436 & 2,50 & & \\
\hline & $1.18-25$ Yaş & 100 & 2,73 & 1,343 & 2,50 & & \\
\hline & 2.26-35 Yaş & 101 & 2,50 & 1,164 & 2,38 & & $0,021 *$ \\
\hline \multirow[t]{5}{*}{ Etik Tüketici Ölçeği } & 3.36-45 Yaş & 93 & 2,10 & 1,194 & 1,63 & 11,499 & Fark: \\
\hline & 4.46-55 Yaş & 71 & 2,39 & 1,190 & 2,00 & & $1-3$ \\
\hline & 5.56 Yaş ve Üzeri & 37 & 2,55 & 1,509 & 1,88 & & \\
\hline & $1.18-25$ Yaş & 100 & 2,73 & 1,486 & 2,13 & & \\
\hline & 2.26-35 Yaş & 101 & 3,23 & 1,373 & 3,50 & & $0,032 *$ \\
\hline \multirow[t]{3}{*}{ Marka Odaklılık } & 3.36-45 Yaş & 93 & 3,60 & 1,297 & 4,00 & 4,600 & Fark: \\
\hline & 4.46-55 Yaş & 71 & 3,21 & 1,465 & 3,75 & & $1-3$ \\
\hline & 5.56 Yaş ve Üzeri & 37 & 3,18 & 1,663 & 3,75 & & \\
\hline
\end{tabular}

*:p<0,05 (İstatistiksel olarak anlamli) $\quad$ K.W.: Kruskal Wallis

Uygulanan Kruskal Wallis analizi sonucunda yaş grupları arasında "yasal olmayan bir durumdan aktif bir şekilde yararlanma” skorları bakımından istatistiksel olarak anlamlı farklılık bulunmamaktadır ( $\mathrm{p}>0,05)$. Bu doğrultuda H2a (Tüketicilerin yasal olmayan bir durumdan aktif bir şekilde yararlanma faktörü yaş gruplarına göre farklılık göstermektedir.) hipotezi doğrulanmamıştır. Yaş grupları arasında "zararsız olarak algılanan eylemlerden yararlanma” ve "Etik Tüketici Ölçeği” skorları bakımından istatistiksel olarak anlamlı farklılık bulunmaktadır $(\mathrm{p}<0,05)$. Bu doğrultuda H2 (Tüketicilerin etik davranışları yaş gruplarına göre farklılık göstermektedir.) ve $\mathrm{H} 2 \mathrm{~b}$ (Tüketicilerin zararsız olarak algılanan eylemlerden yararlanma faktörü yaş gruplarına göre farklılık göstermektedir.) hipotezleri doğrulanmıştır. Buna göre 3645 yaş grubundaki kişilerin "zararsız olarak algılanan eylemlerden yararlanma” skorları 18-25 ve 26-35 yaş grubundaki kişilerden anlamlı derecede daha düşüktür. 36-45 yaş grubundaki kişilerin "Etik Tüketici Ölçeği” skorları 18-25 yaş grubundaki kişilerden anlamlı derecede daha düşüktür. 
Yaş grupları arasında "marka odaklılık" skorları bakımından istatistiksel olarak anlamlı farklılık bulunmaktadır ( $\mathrm{p}<0,05)$. Bu doğrultuda H6b (Tüketicilerin marka odaklı tüketici karar verme tarzı yaş gruplarına göre farklılık göstermektedir.) hipotezi doğrulanmıştır. 36-45 yaş grubundaki kişilerin "marka odaklılık" skorları 18-25 yaş grubundaki kişilerden anlamlı derecede daha yüksektir.

Katılımcıların etik tüketici davranışlarının ve marka odaklı karar verme tarzlarının eğitim düzeylerine göre gösterdikleri farklılıklar Tablo 6'daki gibidir.

Tablo 6. Eğitim Düzeylerine Göre Etik Tüketici Ölçeği ve Alt Boyutları ile Marka Odaklılık Farklıliklarının İncelenmesi

\begin{tabular}{|c|c|c|c|c|c|c|c|}
\hline & & Sayı & Ortalama & St.Sapma & Medyan & K.W. & $\mathbf{p}$ \\
\hline \multirow{6}{*}{$\begin{array}{l}\text { Yasal Olmayan Bir } \\
\text { Durumdan Aktif Bir } \\
\text { Şekilde Yararlanma }\end{array}$} & 1.İlköğretim & 28 & 3,74 & 1,195 & 4,00 & \multirow{6}{*}{151,960} & \multirow{6}{*}{$\begin{array}{l}0,000 * \\
\text { Fark } \\
1-3,4,5,6 \\
2-4,5,6 \\
3-4,5,6\end{array}$} \\
\hline & 2.Lise & 72 & 3,27 & 1,315 & 3,63 & & \\
\hline & 3.Ön Lisans & 81 & 2,44 & 1,284 & 2,50 & & \\
\hline & 4.Lisans & 106 & 1,57 & 1,004 & 1,00 & & \\
\hline & 5.Yüksek Lisans & 68 & 1,24 & 0,400 & 1,00 & & \\
\hline & 6.Doktora & 47 & 1,20 & 0,353 & 1,00 & & \\
\hline \multirow{6}{*}{$\begin{array}{l}\text { Zararsiz Olarak } \\
\text { Algilanan } \\
\text { Eylemlerden } \\
\text { Yararlanma }\end{array}$} & 1.Ilköğretim & 28 & 4,20 & 1,015 & 4,50 & \multirow{6}{*}{182,837} & \multirow{6}{*}{$\begin{array}{l}0,000 * \\
\text { Fark } \\
1-4,5,6 \\
2-4,5,6 \\
3-4,5,6\end{array}$} \\
\hline & 2.Lise & 72 & 4,02 & 1,036 & 4,25 & & \\
\hline & 3.Ön Lisans & 81 & 3,49 & 1,118 & 4,00 & & \\
\hline & 4.Lisans & 106 & 2,26 & 1,133 & 2,00 & & \\
\hline & 5.Yüksek Lisans & 68 & 1,78 & 0,668 & 1,75 & & \\
\hline & 6.Doktora & 47 & 1,65 & 0,724 & 1,50 & & \\
\hline \multirow{6}{*}{ Etik Tüketici Ölçeği } & 1.İlköğretim & 28 & 3,97 & 0,986 & 4,31 & \multirow{6}{*}{193,640} & \multirow{6}{*}{$\begin{array}{l}0,000 * \\
\text { Fark } \\
1-3,4,5,6 \\
2-4,5,6 \\
3-4,5,6\end{array}$} \\
\hline & 2.Lise & 72 & 3,65 & 1,048 & 4,00 & & \\
\hline & 3.Ön Lisans & 81 & 2,96 & 1,070 & 3,00 & & \\
\hline & 4.Lisans & 106 & 1,91 & 0,971 & 1,50 & & \\
\hline & 5.Yüksek Lisans & 68 & 1,51 & 0,437 & 1,50 & & \\
\hline & 6.Doktora & 47 & 1,42 & 0,457 & 1,25 & & \\
\hline \multirow{6}{*}{ Marka Odaklılık } & 1.İlköğretim & 28 & 1,46 & 0,719 & 1,25 & \multirow{6}{*}{215,352} & \multirow{6}{*}{$\begin{array}{l}0,000 * \\
\text { Fark: } \\
1-3,4,5,6 \\
2-4,5,6 \\
3-4,5,6\end{array}$} \\
\hline & 2.Lise & 72 & 1,83 & 0,863 & 1,50 & & \\
\hline & 3.Ön Lisans & 81 & 2,36 & 1,013 & 2,00 & & \\
\hline & 4.Lisans & 106 & 3,97 & 1,204 & 4,38 & & \\
\hline & 5.Yüksek Lisans & 68 & 4,33 & 0,818 & 4,50 & & \\
\hline & 6.Doktora & 47 & 4,28 & 0,683 & 4,50 & & \\
\hline
\end{tabular}

*:p<0,05 (Istatistiksel olarak anlamli) K.W.: Kruskal Wallis

Uygulanan Kruskal Wallis analizi sonucunda eğitim grupları arasında "yasal olmayan bir durumdan aktif bir şekilde yararlanma", "zararsız olarak algılanan eylemlerden yararlanma”, "Etik Tüketici Ölçeği” skorları bakımından istatistiksel olarak anlamlı farklılık bulunmaktadır $(\mathrm{p}<0,05)$. Bu doğrultuda H3 (Tüketicilerin etik davranışları eğitim düzeylerine göre farklılık göstermektedir.), H3a (Tüketicilerin yasal olmayan bir durumdan aktif bir şekilde yararlanma faktörü eğitim düzeylerine göre farklılık göstermektedir.) ve H3b (Tüketicilerin zararsız olarak algılanan eylemlerden yararlanma faktörü eğitim düzeylerine göre farklılık göstermektedir.) 
hipotezleri doğrulanmıştır. Buna göre eğitim düzeyi ilköğretim olan kişilerin "yasal olmayan bir durumdan aktif bir şekilde yararlanma” skorları eğitim düzeyi, ön lisans, lisans, yüksek lisans, doktora olan kişilerden anlamlı derecede daha fazladır. Eğitim düzeyi, lise olan kişilerin "yasal olmayan bir durumdan aktif bir şekilde yararlanma" skorları eğitim düzeyi lisans, yüksek lisans, doktora olan kişilerden anlamlı derecede daha fazladır. Eğitim düzeyi, ön lisans olan kişilerin "yasal olmayan bir durumdan aktif bir şekilde yararlanma” skorları eğitim düzeyi lisans, yüksek lisans, doktora olan kişilerden anlamlı derecede daha fazladır. Eğitim düzeyi ilköğretim olan kişilerin "zararsız olarak algılanan eylemlerden yararlanma” skorları eğitim düzeyi lisans, yüksek lisans, doktora olan kişilerden anlamlı derecede daha fazladır. Eğitim düzeyi, lise olan kişilerin "zararsız olarak algılanan eylemlerden yararlanma” skorları eğitim düzeyi lisans, yüksek lisans, doktora olan kişilerden anlamlı derecede daha fazladır. Eğitim düzeyi, ön lisans olan kişilerin "zararsız olarak algılanan eylemlerden yararlanma” skorları eğitim düzeyi lisans, yüksek lisans, doktora olan kişilerden anlamlı derecede daha fazladır. Eğitim düzeyi ilköğretim olan kişilerin "Etik Tüketici Ölçeği” skorları eğitim düzeyi ön lisans, lisans, yüksek lisans, doktora olan kişilerden anlamlı derecede daha fazladır. Eğitim düzeyi lise olan kişilerin "Etik Tüketici Ölçeği” skorları eğitim düzeyi lisans, yüksek lisans, doktora olan kişilerden anlamlı derecede daha fazladır. Eğitim düzeyi ön lisans olan kişilerin "Etik Tüketici Ölçeği” skorları eğitim düzeyi lisans, yüksek lisans, doktora olan kişilerden anlamlı derecede daha fazladır.

Uygulanan Kruskal Wallis analizi sonucunda eğitim grupları arasında "marka odaklılık" skorları bakımından istatistiksel olarak anlamlı farklılı bulunmaktadır $(\mathrm{p}<0,05) . \mathrm{Bu}$ doğrultuda H6c (Tüketicilerin marka odaklı tüketici karar verme tarzı eğitim düzeylerine göre farklılık göstermektedir.) hipotezi doğrulanmıştır. Eğitim düzeyi ilköğretim olan kişilerin "marka odaklılık" skorları eğitim düzeyi ön lisans, lisans, yüksek lisans, doktora olan kişilerden anlamlı derecede daha düşüktür. Eğitim düzeyi lise olan kişilerin "marka odaklılık” skorları eğitim düzeyi lisans, yüksek lisans, doktora olan kişilerden anlamlı derecede daha düşüktür. Eğitim düzeyi ön lisans olan kişilerin "marka odaklılık” skorları eğitim düzeyi lisans, yüksek lisans, doktora olan kişilerden anlamlı derecede daha düşüktür.

Katılımcıların etik tüketici davranışlarının ve marka odaklı karar verme tarzlarının gelir gruplarına göre gösterdikleri farklılıklar Tablo 7’deki gibidir. 
Tablo 7. Gelir Gruplarına Göre Etik Tüketici Ölçeği ve Alt Boyutları ile Marka Odaklılık Farklılıklarının İncelenmesi

\begin{tabular}{|c|c|c|c|c|c|c|c|}
\hline & & Sayı & Ortalama & St.Sapma & Medyan & K.W. & $\mathbf{p}$ \\
\hline \multirow{5}{*}{$\begin{array}{l}\text { Yasal Olmayan Bir } \\
\text { Durumdan Aktif Bir } \\
\text { Şekilde Yararlanma }\end{array}$} & 1.2021 TL'den Az & 102 & 3,15 & 1,394 & 3,38 & \multirow{5}{*}{116,783} & \multirow{5}{*}{$\begin{array}{l}0,000 * \\
\text { Fark } \\
1-2,3,4,5 \\
2-3,4,5\end{array}$} \\
\hline & $2.2021-5000 \mathrm{TL}$ & 143 & 2,26 & 1,318 & 1,75 & & \\
\hline & $3.5001-8000 \mathrm{TL}$ & 83 & 1,30 & 0,691 & 1,00 & & \\
\hline & $4.8001-11000 \mathrm{TL}$ & 51 & 1,26 & 0,421 & 1,00 & & \\
\hline & 5.11000 TL Üzeri & 23 & 1,21 & 0,367 & 1,00 & & \\
\hline \multirow{5}{*}{$\begin{array}{l}\text { Zararsiz Olarak } \\
\text { Algilanan } \\
\text { Eylemlerden } \\
\text { Yararlanma }\end{array}$} & 1.2021 TL'den Az & 102 & 3,94 & 1,055 & 4,00 & \multirow{5}{*}{165,499} & \multirow{5}{*}{$\begin{array}{l}0,000 * \\
\text { Fark } \\
1-2,3,4,5 \\
2-3,4,5\end{array}$} \\
\hline & $2.2021-5000 \mathrm{TL}$ & 143 & 3,15 & 1,260 & 3,25 & & \\
\hline & $3.5001-8000 \mathrm{TL}$ & 83 & 1,81 & 0,904 & 1,50 & & \\
\hline & $4.8001-11000 \mathrm{TL}$ & 51 & 1,74 & 0,661 & 1,75 & & \\
\hline & 5.11000 TL Üzeri & 23 & 1,58 & 0,610 & 1,50 & & \\
\hline \multirow{5}{*}{ Etik Tüketici Ölçeği } & $1.2021 \mathrm{TL}$ 'den $\mathrm{Az}$ & 102 & 3,55 & 1,113 & 3,94 & & \multirow{5}{*}{$\begin{array}{l}0,00{ }^{*} \\
\text { Fark } \\
1-2,3,4,5 \\
2-3,4,5\end{array}$} \\
\hline & $2.2021-5000 \mathrm{TL}$ & 143 & 2,70 & 1,183 & 2,50 & & \\
\hline & $3.5001-8000 \mathrm{TL}$ & 83 & 1,56 & 0,689 & 1,38 & 169,193 & \\
\hline & $4.8001-11000 \mathrm{TL}$ & 51 & 1,50 & 0,443 & 1,38 & & \\
\hline & 5.11000 TL Üzeri & 23 & 1,39 & 0,440 & 1,25 & & \\
\hline \multirow{5}{*}{ Marka Odaklılık } & 1.2021 TL'den Az & 102 & 1,80 & 0,816 & 1,50 & & \multirow{5}{*}{$\begin{array}{l}0,000 * \\
\text { Fark } \\
1-2,3,4,5 \\
2-3,4,5\end{array}$} \\
\hline & $2.2021-5000 \mathrm{TL}$ & 143 & 2,95 & 1,362 & 3,00 & & \\
\hline & $3.5001-8000 \mathrm{TL}$ & 83 & 4,23 & 0,964 & 4,50 & 181,555 & \\
\hline & $4.8001-11000 \mathrm{TL}$ & 51 & 4,39 & 0,881 & 4,75 & & \\
\hline & 5.11000 TL Üzeri & 23 & 4,32 & 0,565 & 4,25 & & \\
\hline
\end{tabular}

*:p<0,05 (İstatistiksel olarak anlamli) K.W.: Kruskal Wallis

Uygulanan Kruskal Wallis analizi sonucunda gelir grupları arasında "yasal olmayan bir durumdan aktif bir şekilde yararlanma”, "zararsız olarak algılanan eylemlerden yararlanma”, "Etik Tüketici Ölçeği” skorları bakımından istatistiksel olarak anlamlı farklılık bulunmaktadır $(\mathrm{p}<0,05)$. Bu doğrultuda, H4 (Tüketicilerin etik davranışları gelir düzeylerine göre farklılık göstermektedir.), H4a (Tüketicilerin yasal olmayan bir durumdan aktif bir şekilde yararlanma faktörü gelir düzeylerine göre farklılık göstermektedir.) ve H4b (Tüketicilerin zararsız olarak algılanan eylemlerden yararlanma faktörü gelir düzeylerine göre farklılık göstermektedir.) hipotezleri doğrulanmıştır. Buna göre, gelir durumu 2021 TL'den az olan kişilerin “yasal olmayan bir durumdan aktif bir şekilde yararlanma", "zararsız olarak algılanan eylemlerden yararlanma”, "Etik Tüketici Ölçeği” skorları gelir durumu 2021-5000 TL, 5001-8000 TL, 800111000 TL ve 11000 TL üzeri olan kişilerden anlamlı derecede daha fazladır. Gelir durumu 20215000 TL olan kişilerin "yasal olmayan bir durumdan aktif bir şekilde yararlanma”, "zararsız olarak algılanan eylemlerden yararlanma”, "Etik Tüketici Ölçeği” skorları gelir durumu 50018000 TL, 8001-11000 TL ve 11000 TL üzeri olan kişilerden anlamlı derecede daha fazladır.

Uygulanan Kruskal Wallis analizi sonucunda gelir grupları arasında "marka odaklılık" skorları bakımından istatistiksel olarak anlamlı farklılık bulunmaktadır ( $\mathrm{p}<0,05)$. Bu doğrultuda, H6d (Tüketicilerin marka odaklı tüketici karar verme tarzı gelir düzeylerine göre farklılık göstermektedir.) hipotezi doğrulanmıştır. Gelir durumu, 2021 TL'den az olan kişilerin "marka odaklılık" skorları gelir durumu, 2021-5000 TL, 5001-8000 TL, 8001-11000 TL ve 11000 TL 
üzeri olan kişilerden anlamlı derecede daha düşüktür. Gelir durumu 2021-5000 TL olan kişilerin "marka odaklllı" skorları gelir durumu 5001-8000 TL, 8001-11000 TL ve $11000 \mathrm{TL}$ üzeri olan kişilerden anlamlı derecede daha düşüktür.

\section{Sonuç ve Öneriler}

Bu çalışmada, tüketici etik davranışı ile marka odaklı tüketici karar verme tarzı arasındaki ilişkinin tespit edilmesi amaçlanmıştır. Araştırmada ayrıca, tüketici etik davranışının ve marka odaklı karar verme tarzının tüketicilerin demografik özelliklerine göre (yaş, cinsiyet, eğitim ve gelir düzeyi) nasıl farklılıklar gösterdiği de tespit edilmiştir. Elde edilen sonuçlara göre tüketicilerin etik davranışları ile marka odaklı karar verme tarzları arasında anlamlı ve negatif yönde ilişki bulunmaktadır. Etik tüketici davranışının "yasal olmayan bir durumdan aktif bir şekilde yararlanma" ve "zararsız olarak algılanan eylemlerden yararlanma" faktörleri ile marka odaklı karar verme tarzı arasında aynı şekilde anlamlı ve negatif yönde bir ilişki bulunmaktadır. Bu durumda, etik tüketici davranışı gösteren tüketicilerin marka odaklı tüketiciler oldukları söylenilebilir. İlgili literatür tarandığında etik tüketici davranışı ile marka odaklı karar verme tarzı arasındaki ilişkinin incelenmesine dair bir araştırmaya rastlanılmamıştır. Ancak yapılan araştırmalarda genç tüketicilerin, etik ürün ile ilgi yeterli bilgiye sahip olmasına rağmen kendilerini marka ile özdeşleştirmeleri gibi sebeplerden; yetişkin tüketicilerin ise bilgi eksikliği, etik farkındalığının oluşmamış olması ve etik ürüne ulaşmak için çaba göstermenin motivasyonu düşürmesi gibi sebeplerden etik dışı üretim yapan markayı tercih ettikleri görülmektedir (Meydan, 2017).

$\mathrm{Bu}$ çalışmada, eğitim ve gelir düzeyi ile etik tüketici davranışı arasında anlamlı bir ilişki olduğu, eğitim ile gelir düzeyi yüksek tüketicilerin ve 36-45 yaş aralığında olan tüketicilerin 18-25 yaş aralığında olan tüketicilere göre daha etik tüketici davranışı gösterdikleri tespit edilmiştir. Muncy ve Vitell (1992), eğitim ve gelir düzeyi düşük tüketicilerin etik olmayan konulara daha fazla duyarlı olduklarını tespit etmişlerdir. Araştırmada ayrıca katılımcıların marka odaklı karar verme tarzları ile demografik özellikleri arasında anlamlı bir ilişki olduğu görülmüştür. Erkek tüketicilerin kadın tüketicilere göre; 36-45 yaş aralığındaki tüketicilerin 18-25 yaş aralığındaki tüketicilere göre; doktora, yüksek lisans ve lisans düzeyinde eğitimi olan tüketicilerin ilköğretim, lise ve önlisans eğitim düzeyinde olan tüketicilere göre ve geliri yüksek olan tüketicilerin geliri düşük olan tüketicilere göre marka odaklı karar verme tarzı gösterdikleri tespit edilmiştir. Nitekim, iyi bir mesleğe sahip, gelir durumu yüksek ve yüksek yaşam standardı olan tüketicilerin daha yüksek fiyatlı ve kaliteli ürünler tercih ettikleri görülmektedir (Aktuğlu ve Temel, 2006). Hazer (2012) ise yapmış olduğu çalışmada, eğitim düzeyi yükseldikçe tüketicilerin "kısmen zararsız olarak algılanan davranışlar"ı daha etik bulduklarını, farklı gelir düzeyinde olan tüketiciler ile etik tüketici davranışı arasında ise istatistiksel olarak anlamlı bir ilişki bulunmadığını belirtmektedir.

Araştırmada elde edilen bir diğer sonuç, tüketicilerin etik davranışları ile cinsiyetleri arasında bir ilişki olmadığı yönündedir. Saray ve Hazer, 2017 yllında yapmış olduğu araştırmada benzer sonuca ulaşmışlardır. Altay (2016) ve Varinli (2000) ise kadın tüketicilerin etik ilkelere daha çok dikkat ettiklerini belirtmektedirler. 
Elde edilen bu bulgular doğrultusunda aşağıda verilen öneriler geliştirilmiştir:

- İşletmelerin, pazarlama etiğini ve etik tüketicileri dikkate alarak sosyal sorumluluk projelerine ağırlık vermeleri ve etik sorumluluklarını üstlenmeleri hem toplumsal anlamda olumlu yönde gelişimi hem de markalarının açıldıkları pazarda başarılı olmalarını kolaylaştıracaktır.

- İşletmelerin, pazara sunacakları yeni markaları olduğunda veya mevcut markalarına yönelik geliştirdikleri stratejilerinde etik tüketici davranışı gösteren tüketicileri de dikkate alarak tutundurma çalışmaları yapmalarının daha başarılı olmalarını sağlayacağı düşünülmektedir.

- İşletmelerin tüketicilerin etik davranış düzeylerini ve bu davranışlarını etkileyen faktörleri tespit ederek markalarının hedef kitlelerini tanımaları, bu tüketicilerin istek ve ihtiyaçlarını daha isabetli tespit etmeleri açısından önem taşımaktadır.

- İşletmeler; kamu kuruluşları, özel sektörler veya diğer markalar ile yapacakları işbirliği aracılığıyla etik tüketici davranışına ilişkin kamu spotları hazırlayarak veya çeşitli bilgilendirici çalışmalar yaparak tüketicilerin daha bilinçli olmalarını sağlayabilirler. Nitekim etik tüketici davranışının noksanlığı, sadece işletmelerin değil tüm toplumu ilgilendiren ahlaki bir sorumluluk olarak değerlendirilmelidir.

- Örneklem bakımından Ankara ve Samsun şehirlerini kapsaması bu araştırmanın kısıtı olarak değerlendirilmektedir. Bu nedenle etik tüketici davranışına ilişkin daha geniş kapsamlı, farklı kültür ve bölgelerden oluşan tüketicilerle yapılan çalışmalar ilgili literatüre katkı sağlayacaktır. Etik tüketici davranışı ile tüketici karar verme tarzlarının diğer faktörleri ile ilişkisine dair yapılacak çalışmaların işletmeler ve uygulayıcılar açısından daha aydınlatıcı olacağı düşünülmektedir. Ayrıca etik tüketici davranışının sektör bazında ele alınması, tüketici istek ve ihtiyaçlarının tespit edilmesinde daha spesifik sonuçlar elde edilmesini kolaylaştıracaktır. 


\section{Kaynakça}

Aaker, J. L. (1997). Dimensions of Brand Personality. Journal of Marketing Research, 34(3), 347356.

Aktuğlu, I. K., Temel, A. (2006), Tüketiciler Markaları Nasıl Tercih Ediyor? (Kamu Sektörü Çalışanlarının Giysi Markalarını Tercihini Etkileyen Faktörlere Yönelik Bir Araştırma). Selcuk University Social Sciences Institute Journal, 15, 43-59

Al-Khatib J. A., Dobıe K., Vitell, S. J. (1995). Consumer Ethics in Developing Countries: An Empirical Investigation. Journal of Euromarketing, 4(2), 87-109.

Al-Khatib J. A., Vitell, S. J., Scott, J., Rawwas, M. Y. A. (1997). Consumer Ethics: A CrossCultural Investigation, European Journal of Marketing, 31(11-12), 750-767.

Altay, Ş. (2016). Tüketicilerin Etik Algılamaları Üzerinde Demografik Faktörlerin Etkisinin Araştırılmasına Yönelik Bir Araştırma, Ardahan Üniversitesi İktisadi ve İdari Bilimler Fakültesi Dergisi, 3, 201-215.

Anić, I. D., Ciunova-Shuleska, A., Rajh, S. P., Rajh, E., Bevanda, A. (2016). Differences in Consumer Decision-Making Styles among Selected South-East European Countries, Economic Research-Ekonomska Istraživanja, 29(1), 665-681.

Anić, I. D., Piri Rajh, S., Rajh, E. (2014). Antecedents of Food-Related Consumer DecisionMaking Styles, British Food Journal, 116(3), 431-450.

Arli, D., Pekerti, A. (2016). Who is More Ethical? Cross-Cultural Comparison of Consumer Ethics Between Religious and Non-Religious Consumers, Journal of Consumer Behaviour, 16(1), 82-98.

Arli, D., Cheryl, L. (2017). Why Do Good People Do Bad Things? The Effect of Ethical İdeology, Guilt Proneness, and Self-Control on Consumer Ethics, Asia Pacific Journal of Marketing and Logistics, 29(5), doi: 10.1108/APJML-11-2016-0218

Bakewell C., Vincent-Wayne M. (2006). Male Versus Female Consumer Decision Making Styles. Journal of Business Research, 59, 1297-1300.

Buğday, E. B., Babaoğul, M. (2016). Bilinçli Tüketim Kavramının Boyutları: Bilinçli Tüketim Davranışının Yeniden Tanımlanması, Sosyoekonomi, 24(30), 187-206.

Chan, A., Wong, S., Leung, P. (1998). Ethical Beliefs of Chinese Consumers in Hong Kong”. Journal of Business Ethics, 17(11), 1163-1170.

Chernatony, L. (2009). Towards the Holy Grail of Defining 'Brand, Marketing Theory, 9(1), 101105. 
Cowart, K. O., Goldsmith, R. E. (2007). The Influence of Consumer Decision- Making Styles on Online Apparel Consumption by College Students. International Journal of Consumer Studies, 31(6), 639-647.

Culiberg, B., Bajde, D. (2013). Consumer Recycling: An Ethical Decision-Making Process, Journal of Consumer Behaviour, 12(6), 449-459.

Dursun, İ., Alnıaçı, Ü., Kabadayı, E. T. (2013). Tüketici Karar Verme Tarzları Ölçeği: Yapısı \& Boyutları, Uluslararası Yönetim İktisat ve İsletme Dergisi, 9(19), 293-304.doi: 10.11122/ijmeb.2013.9.19.418

Dursun, İ., Kabadayı, E. T., Tuğer, A. T. (2016). Sorumlu Tüketim: Neden? Nasıl?, Müberra Babaoğul, Arzu Şener, Betül Buğday (Ed.), Tüketici Yazıları V içinde (s. 9-39). Ankara: Hacettepe Üniversitesi Tüketici-Pazar-Araştırma-Danışma Test ve Eğitim Merkezi.

Ecer, F. (2006). Tüketici Etiğinin Oluşumuna Etki Eden Etmenler ve Bir Uygulama. Mevzuat Dergisi, 9(103), 1-10.

Engizek, N., Şekerkaya, A. (2016). X ve Y Kuşağı Kadınlarının Karar Verme Tarzları Bakımından İncelenmesi, Mustafa Kemal Üniversitesi Sosyal Bilimler Enstitüsü Dergisi, 13(36), 242-271.

Erciş, A., Altay, Ş., Türk, B. (2017). Tüketici Etiğinin Yeniden Satın Alma Davranışı Üzerindeki Etkisinin Suçluluk Duygusu Bağlamında İncelenmesi, Atatürk Üniversitesi İktisadi ve İdari Bilimler Dergisi, 31(2), 229-242.

Erciş, A., Türk, B. (2016). Etik Çerçevesinde Tüketim, Tüketici ve Çevre: Ekolojik Okuryazarlığın Moderatör Rolü, Çukurova Üniversitesi İIBBF Fakültesi Dergisi, 20(2), 1 24.

Erffmeyer R.C., Keillor B.D., Leclair, D. T. (1999). An Empirical Investigation of Japanese Consumer Ethics, Journal of Business Ethics, 18(1), 35-50.

Ergin, T. D., Esen, S. K., Tuzla, H. (2016). Genç Tüketicilerin Karar Verme Stilleri ile Sms Reklamlarına Yönelik Tutumları Arasındaki Farkların İncelenmesi. Yönetim ve Ekonomi Araştırmaları Dergisi, 14(2), 18-40. doi: 10.11611/JMER773.

Ertuhan, H., Filizöz, B. (2011). İş Etiği ve Bankacılık Sektöründe Bir Araştırma. Cumhuriyet Üniversitesi İktisadi ve İdari Bilimler Dergisi, 12(2), 139-157

Ferrell, O.C., Gresham, L. G. (1985). A Contingency Framework for Understanding Ethical Decision Making in Marketing, Journal of Marketing, 49(3), 87-96. doi: 10.1177/002224298504900308

Gummerus, J., Liljander, V., Sihlman, R. J. (2017). Do Ethical Social Media Communities Pay Off? An Exploratory Study of the Ability of Facebook Ethical Communities to 
Strengthen Consumers' Ethical Consumption Behavior, Journal of Business Ethics, 144(3), 449-465. doi. 10.1007/s10551-015-2830-y

Hafstrom, J.L., Chae, J.S., Chung, Y.S. (1992). Consumer Decision-Making Styles: Comparison between United States and Korean Young Consumers. The Journal of Consumer Affairs, 26(1), 146-158.

Hazer, O. (2012). Tüketicilerin Etik İnançlarının İncelenmesi. Zeynep Çopur ve Oya Hazer (Ed.), I. Uluslararası Aile ve Tüketici Bilimleri Kongresi Bildiri Kitabı içinde (s. 1-23), Antalya.

Hazer, O., Öztürk, M. S. (2013). Elderly Consumers and Ethics. European Conference on Social and Behavioral Sciences, 1-22. url'si http://docplayer.biz.tr/698216-Europeanconference-on-social-and-behavioral-sciences-june-19-21-2013-faculty-of-businessadministration-marmara-university.html, Erişim Tarihi 20 Mart 2019.

Jegethesan, K., Sneddon, J. N., Soutar, G. (2012). Young Australian Consumers' Preferences For Fashion Apparel Attributes. Journal of Fashion Marketing and Management, 16(3), 275289.

Kavak, B., Gürel, E., Eryiğit, Özkan, Ö. (2009). Examining the Effects of Moral Development Level, Self-Concept, and Self-Monitoring on Consumers' Ethical Attitudes. Journal of Business Ethics, 88(1), 115-135.

Knapp, E. D. (1999). The Brand Mindset, New York: Inc McGraw-Hill Professional

Levin, A., Dato-On, M. C., Rhee, K. (2004). Money For Nothing and Hits For Free: The Ethics of Downloading Music From Peer-To-Peer Web Sites. Journal of Marketing Theory and Practice, 12(1), 48-60.

Lu, L. C., Lu, C.J. (2010). Moral Philosophy, Materialism, and Consumer Ethics: An Exploratory Study in Indonesia. Journal of Business Ethics, 94(2), 193-210.

Lu, LC., Chang, H. H., Chang, A. (2015). Consumer Personality and Green Buying Intention: The Mediate Role of Consumer Ethical Beliefs, Journal of Business Ethics, 127(1), 205209. doi: 10.1007/s10551-013-2024-4

Lysonski, S., Durvasula, S. (2013). Consumer Decision Making Styles in Retailing: Evolution of Mindsets and Psychological Impacts, Journal of Consumer Marketing, 30(1), 75-87.

Masuda, A., Ishii, H., Onzo, N. (2019). Effects on Consumer Attitudes of Appeal Information of Ethical Products, A Study on Socio-cultural Influences of Inclusive Business, 189, 1-33.

Meydan, B. (2017). Etik Tüketicinin Kozmetik Ürünü Satın Alma Kararı: PROMETHEE Tekniği ile Bir Uygulama, Uluslararası Akademik Yönetim Bilimleri Dergisi, 3(4), 233259. 
Morrow, V., Richards, M. (1996). The Ethics of Social Research with Children: An Overview. Children and Society, 10(2), 90-105.

Muncy, J. A., Vitell, S. J. (1992). Consumer Ethics: An Investigation of the Ethical Beliefs of the Final Consumer, Journal of Business Research, 24(4), 297-311.

Owunwanne, D., Rustag1, N., dada, R. (2010). Students' Perceptions of Cheating and Plagiarism in Higher Institutions, Journal of College Teaching and Learning, 7(11), 59-68.

Oyman, M. (2004). Tüketici Etiği: Ülkelerarası Karşılaştırmalara ve Demografik Faktörlere Dayalı Bir Araştırma, Eskişehir Osmangazi Üniversitesi Sosyal Bilimler Dergisi, 5(2), 77 90.

Özden, A. T. (2019). Pozitif Algının ve Tüketici Karar Verme Tarzlarının Y ve Z Kuşakları Açısından Karşılaştırılması, Gazi İktisat ve İşletme Dergisi, 5(1), 1-20. doi: 10.30855/gjeb.2019.5.1.001

Özkoç, H. H., Gün Eroğlu, Ş., Kazancı, E. (2018). Taklit Ürün ve Tüketici Etiği: Üniversite Öğrencilerinin Açık Parfüm Kullanma Eğilimleri Üzerine Bir Araştırma. Pamukkale Üniversitesi Sosyal Bilimler Enstitüsü Dergisi, 32, 319-332.

Rawwas, M. Y. A., Patzer, G. L., Klassen, M. L. (1995). Consumer Ethics in Cross-Cultural Settings Entrepreneurial Implications, European Journal of Marketing, 29(7), 62-78.

Saray, M. T., Hazer, O. (2017). Etik Tüketici Ölçeğinin Türkçe Uyarlaması; Geçerlilik ve Güvenilirliğine İlişkin Bir Çalışma: Hacettepe Üniversitesi Örneklemi, International Journal of Education Technology and Scientific Researches, 2(4), 258-283.

Schröder, M. J., McEachern, M. G. (2005). Fast Foods and Ethical Consumer Value: A Focus On Mcdonald's and KFC. British Food Journal, 107(4), 212-224.

Shim, S. (1996). Adolescent Consumer Decision-Making Styles: The Consumer Socialization Perspective, Psychology \& Marketing, 13(6), 547-569.

Sproles E. K., Sproles, G. B. (1990). Consumer Decision- Making Styles As A Function of Individual Learning Styles, The Journal of Consumer Affeirs Summer, 24(1), 134-147. doi: 10.1111/j.1745-6606.1990.tb00262.x

Sproles, G. B., Kendall, E. L. (1986). A Methodology For Profiling Consumers' Decision Making Styles. The Journal of Consumer Affairs, 20(2), 267-279. doi: 10.1111/j.17456606.1986.tb00382.x

Swardan, Z., Vitell, S., Rawwas, M. Y. A. (2003). Consumer Ethics: Determinants of Ethical Beliefs of African Americans, Journal of Business Ethics, 46(2), 175-186.

Swaidan, Z., Vitell, S. J., Rose, G. M., Gilbert, F. W. (2006). Consumer Ethics: The Role of Acculturation in U.S. Immigrant Populations, Journal of Business Ethics, 64(1), 1-16. 
Torlak, Ö. (2009). Pazarlama Ahlakı (5. Baskı). İstanbul: Beta.

Torlak, Ö., Tiltay, M. A. (2009). Materyalist Eğilim, Dini Değerler ve Tüketici Ahlakı Arasındaki İlişkiler. Ramazan Kurtoğlu ve Mehmet Kara (Ed.), 14. Ulusal Pazarlama Kongresi Bildiri Kitabı içinde (s. 61-77), Yozgat: Bozok Üniversitesi İktisadi ve idari Bilimler Fakültesi Yayınları.

Ünal, S., Erciş, A. (2007). Genç Pazarın Satın Alma Tarzlarının Belirlenmesi Üzerine Bir Araştırma. Atatürk Üniversitesi İktisadi ve İdari Bilimler Fakültesi Dergisi, 21(1), 321-336.

Varinli, İ. (2000). Tüketici Etiği ve Üniversite Öğrencilerine Yönelik Bir Araştırma. Atatürk Üniversitesi İktisadi ve İdari Bilimler Dergisi, 14(1), 297-309.

Vitell, S. J., Muncy, J. (2005). The Muncy-Vitell Consumer Ethics Scale: A Modification and Application, Journal of Business Ethics, 62(3), 267-275.

Vitell, S. J., Muncy, J. (1992). Consumer Ethics: An Empirical Investigation of Factors Influencing Ethical Judgments of the Final Consumer, Journal of Business Ethics, 11(8), 585-597.

Vitell, S.J., King, R.A., Howie, K., Toti, J. F., Albert, L., Hidalgo, E. R., Yacout, O. (2016). Spirituality, Moral Identity, and Consumer Ethics: A Multi-cultural Study, Journal of Business Ethics, 139(1), 147-160, doi: 10.1007/s10551-015-2626-0

Yurtsever, G. (1998). The Ethical Beliefs of Turkish Consumers, Dokuz Eylül Üniversitesi İktisadi ve İdari Bilimler Fakültesi Dergisi, 13(2), 135-146. 